\title{
REDESIGN DE SHAPE DE LONGBOARD E SKATEBOARD USANDO PAPELÃO COMO SUA MATÉRIA PRIMA
}

\author{
Rafael Dantas de Souza, Designer (UFSC); Paulo Cesar \\ Machado Ferroli, Dr. Eng. (UFSC).
}

\section{INTRODUÇÃO}

Este projeto mostra a aplicação de uma nova matéria prima para a fabricação de pranchas de skateboard e longboard, tendo como material principal o papelão ou derivados, com a intenção de baixar os custos de produção do skate, e tornar sua produção mais sustentável. Isso levará a uma maior propagação do uso do skate. Os principais critérios adotados, por se tratar de um produto voltado para a prática do esporte, foram: formas específicas, material leve, resistente e durável.

\section{Desenvolvimento}

Utilizando-se metodologias de projeto, com ênfase forte no ciclo de vida do produto, realizaram-se vários testes de materiais e processos durante o desenvolvimento.

\subsection{Preparação das Lâminas}

A lâmina de papelão formou o shape Pé Grande foi dimensionada em $80 \mathrm{~cm} \times 24 \mathrm{~cm}$. Devido à particularidade de cada papelão, estes tiveram de ser preparados de forma diferenciada. O papelão ondulado foi cortado em dois modos diferentes a fim de testar suas propriedades; em um ele foi cortado no sentido paralelo as ondas e no outro foi cortado no sentido perpendicular. No caso do papelão couro, paraná e vellumoid foram cortados da mesma maneiras

\subsection{Colagem das Lâminas}

Neste ponto do processo, com as lâminas já estão cortadas e separadas, foi aplicado cola em cada folha de papelão, utilizando-se espátula, pincel e rolo de espuma. Foram testadas dois tipos de cola: adesivo universal (cola de sapateiro) e adesivo a base de resina epóxi. Após a aplicação da cola as camadas de papelão foram empilhadas e prensadas.

\subsection{Prensagem}

Foram usados dois shapes já prontos para o molde, e a prensagem foi feita por compressão utilizando

Figura 1: Processo de construção do skate.

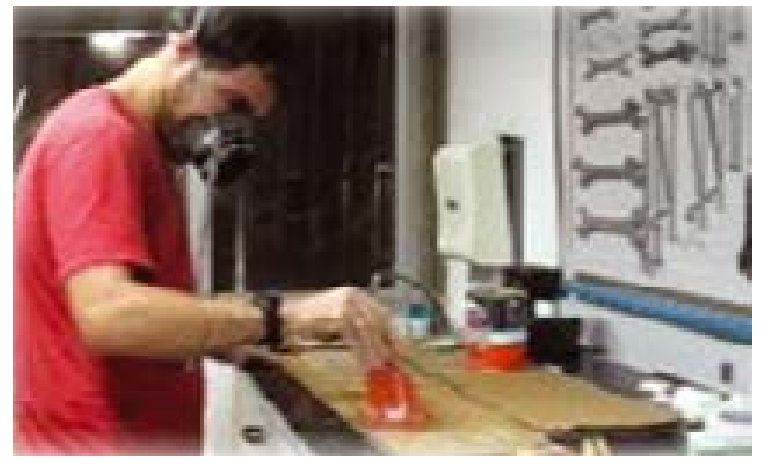

Fonte: Autores.

sargentos para comprimir nas bordas, e também, também utilizou-se um sistema de sanduíche de chapa de aço para comprimir no meio.

\subsection{Corte furação e Acabamento do Shape} Após a cura do shape na prensa (24 horas), ele foi retirado da prensa e cortado no formato final. Para garantir que o formato final fosse respeitado foi utilizado um gabarito. Em seguida foi furado, usando-se novo gabarito, e por fim, acabamento final, com aplicação de duas camadas de selante, três camadas de verniz e pintura ou não. 


\section{CONSIDERAÇÕES FINAIS}

Um produto como o skate traz agregado em si muitas exigências. Os aspectos formais do shape e também os aspectos físicos, demandam que ele seja resistente, flexível, leve, e que respondam com precisam ao manejo dos usuários. Como foi delimitado no inicio do projeto, os estudos realizados não abrangem toda esta complexidade exigida pelo produto. Considerando tudo o que foi estudado e experimentado neste projeto, pode ser concluído que o papelão pode ser um material viável para a produção do shape de skate, porém muitos estudos ainda precisam ser realizados para que isso seja algo concreto. Neste projeto realizou teste preliminar do material, estudo do melhor tipo e uso do adesivo, diferentes métodos de prensagem, disposição diferentes das malhas do papelão ondulado, combinações diferentes entre materiais, papelão couro e papelão vellumoid, papelão couro e papelão paraná, números de camadas diferentes. Testes de resistência assistido por software e com usuário final foram realizados durante e após do término do projeto. Visto o que foi proposto por este projeto podemos concluir que foi bem sucedido, porem mais estudos se mostram necessários.

\section{REFERÊNCIAS}

1. ASHBY, Michael \& Johnson, kara. Materiais e design: arte e ciência na seleção de materiais no design de produto. Rio de janeiro: Elsevier, 2011.

2. BHAMRA, Tracy \& Lofthouse, Vicky. Design for sustainability: a pratical aproach. Humpshire: Gowerpublishing, 2007..2011. 